\title{
Focal mechanisms of small-moderate earthquakes in Denizli Graben (SW Turkey)
}

\author{
T. Serkan Irmak \\ Kocaeli University, Engineering Faculty, Department of Geophysical Engineering, Seismology Section, 41100, Kocaeli, Turkey
}

(Received November 15, 2012; Revised May 13, 2013; Accepted May 20, 2013; Online published October 9, 2013)

\begin{abstract}
The present study seeks to determine the fault mechanisms of small-moderate earthquakes in Denizli Graben in Turkey and to define the relation of the fault mechanism with the regional tectonics. For this purpose, 20 earthquakes, which occurred in the time period 2004-2009, were analyzed. Focal mechanisms were determined using the focmec algorithm and time domain regional waveform inversion techniques. The analyzed earthquakes were characterized by a normal faulting mechanism with a large dip angle and a small amount of strike-slip components. The depths of the earthquakes were located in the range of $6-8 \mathrm{~km}$. The stress inversion of the studied earthquake focal mechanism data show that the present-day stress field is characterized by a pure extensional regime $\left(R^{\prime}=0.74\right)$ and a horizontal direction of extension at $\mathrm{N} 9^{\circ} \mathrm{E}$, close to $\mathrm{N}-\mathrm{S}$. The orientations of the principal stress axes are vertical for $\sigma_{1}$ and horizontal for $\sigma_{2}$ and $\sigma_{3}$. Axis orientations are found as $62^{\circ} / 277^{\circ}, 28^{\circ} / 100^{\circ}$, and $1^{\circ} / 9^{\circ}$ (dip/azimuth direction) for $\sigma_{1}, \sigma_{2}$ and $\sigma_{3}$, respectively. According to the direction of the principal stress axes, Denizli Graben is opening in the direction of NE-SW. The extension rate is calculated as $0.41 \mathrm{~mm} /$ year for the whole of Denizli Graben, using the seismic moment values. Focal mechanism solutions and the directions of the horizontal stresses, $S_{H \max }$ and $S_{h \min }$, inferred from the analysis of the focal mechanisms, show good agreement with the general features for Denizli Graben.
\end{abstract}

Key words: Western Turkey, Anatolia, Denizli Graben, moment tensor, stress inversion.

\section{Introduction}

The tectonic framework of Turkey is dominated by the continental collision of the Eurasian and African plates with Eurasia as shown in Fig. 1 (McKenzie, 1972; Jackson and McKenzie, 1984). The Arabian plate is moving in a northnorthwest direction relative to Eurasia at a rate of about 18 $\mathrm{mm} / \mathrm{yr}$ (McClusky et al., 2000), averaged over about 3 My based on the analysis of global seafloor spreading, fault systems, and earthquake slip vectors. These models also indicate that the African Plate is moving in a northerly direction relative to Eurasia at a rate of about $6 \mathrm{~mm} / \mathrm{yr}$ (McClusky et al., 2000). Different motions between Africa and Arabia $(\sim 8-15 \mathrm{~mm} / \mathrm{yr})$ are thought to be taken up predominantly by the left-lateral motion along the Dead Sea transform fault. This northward motion results in a westward extrusion of the Anatolian Plate.

According to this model, the Anatolian plate is rotating counter-clockwise, relative to Eurasia, about an Euler pole located north of the Sinai peninsula $\left(31.1^{\circ} \mathrm{N}, 33.4^{\circ} \mathrm{E}\right)$, which results in a slip velocity of $24 \mathrm{~mm} / \mathrm{yr}$ for the North Anatolian Fault (McClusky et al., 2000). This westward motion of Anatolia results in an extensional stress field in the Aegean region. Moreover, the Aegean region moves as a more or less coherent unit respect to Eurasia with a much higher velocity $(\sim 30 \mathrm{~mm} / \mathrm{yr})$ than the correspond-

Copyright (C) The Society of Geomagnetism and Earth, Planetary and Space Sciences (SGEPSS); The Seismological Society of Japan; The Volcanological Society of Japan; The Geodetic Society of Japan; The Japanese Society for Planetary Sciences; TERRAPUB.

doi:10.5047/eps.2013.05.011 ing velocity of the Anatolian Plate (Kahle et al., 1998) to the southwest. This complex movement has resulted in the N-S extensional regime created mainly by the motion of the Anatolian Plate and the subduction of the African Plate under the southern margin of the Anatolian Plate. The African Plate subducts the southern margin of the Anatolian Plate, which has caused E-W, NW-SE, NE and NW trending normal faults developing the grabens in the Southwesten Anatolia region (Dewey and Şengör, 1979; Jackson and McKenzie, 1984; Eyidoğan and Jackson, 1985; Taymaz et al., 1991; Taymaz and Price, 1992; Koçyiğit et al., 1999; Gürer et al., 2003; Zhu et al., 2006, among others).

The Southwestern Anatolian region, where Denizli Graben is located, is one of the most active seismic regions in Turkey and consists of a series of E-W, NW-SE and NE-SW trending Grabens such as Bakırçay, Gediz, Küçükmenderes, Büyükmenderes, and Gökova Grabens. Its seismotectonic features are very complex due to block rotation, and dispersed stress accumulation. The pattern of shallow seismicity is scattered over a zone along the major graben systems and characterized by small and moderate earthquakes. Furthermore, historical seismicity records prove that the faults developing these grabens generate earthquakes from moderate to large sizes (Table 1). The Denizli basin is a small and local basin within this region, trending NW-SE, which is also exposed to small to moderate earthquakes.

The determination of earthquake source parameters such as the seismic moment, focal mechanism, and depth, can contribute to earthquake hazard response by quickly char- 


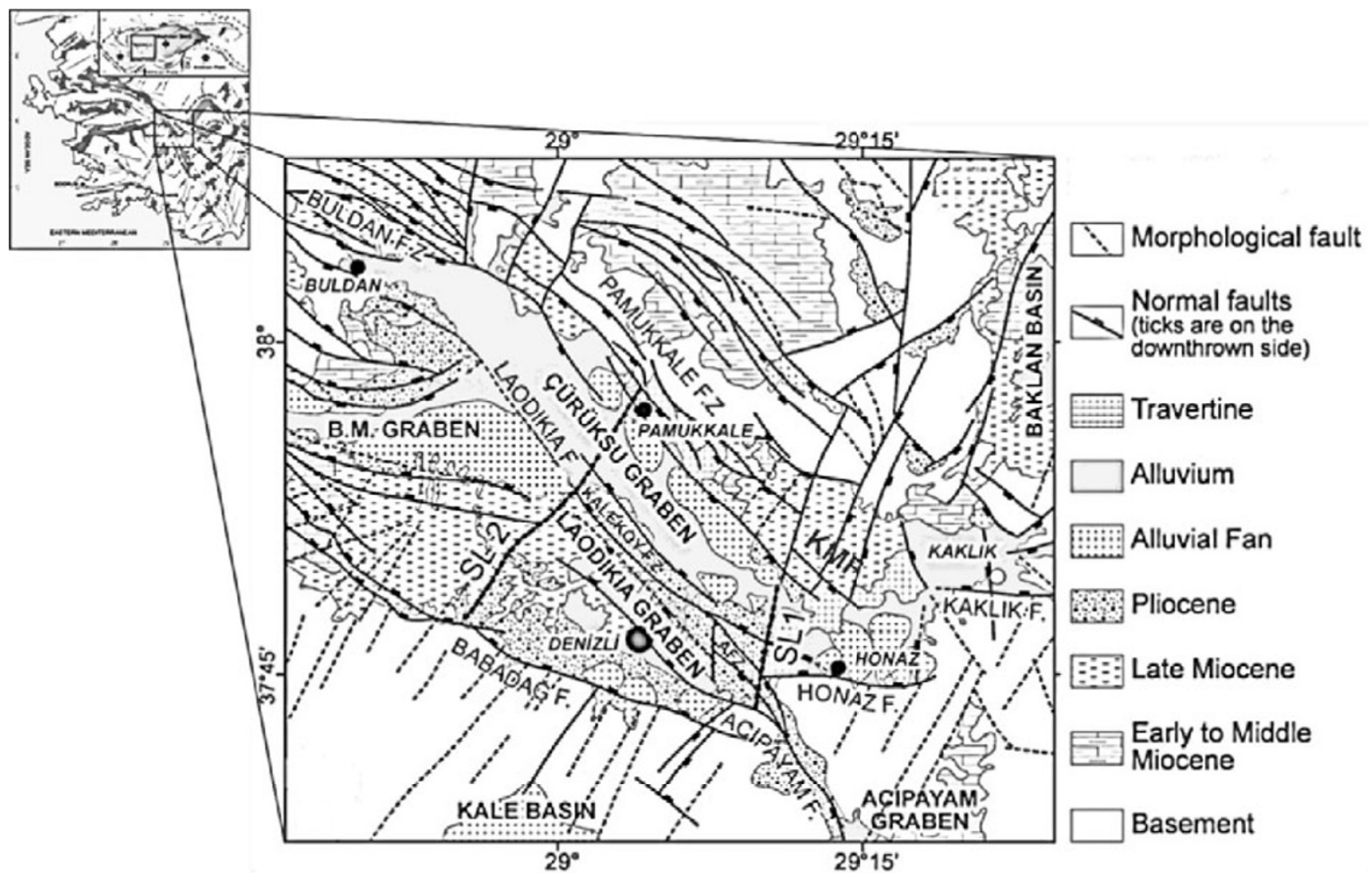

Fig. 1. Geological map of the Denizli Graben System. SL1 and SL2 subsurface structures; AFZ: Aşağıdağdere Fault Zone; KMF: Küçükmalıdağ Fault Zone; B.M. Graben: Büyük Menderes Graben, (modified from Kaymakçı, 2006).

Table 1. Moderate and large earthquakes which have occurred in southwestern Turkey (Ergin et al., 1967; Alsan et al., 1975; Soysal et al., 1981; Ambraseys, 1988; Eyidoğan et al., 1991) since 1900.

\begin{tabular}{rcccccc}
\hline No & Date & Time (local time) & Location & Intensity & Magnitude $\left(M_{\mathrm{s}}\right)$ & Casualties \\
\hline 1 & 04.10 .1904 & $00: 07$ & Burdur & IX & 6.9 & 300 \\
2 & 19.07 .1933 & $22: 07$ & Çivril-Denizli & VIII & 5.7 & 20 \\
3 & 30.01 .1964 & $19: 45$ & Tefenni-Burdur & VIII & 5.7 & - \\
4 & 13.06 .1965 & $22: 01$ & Denizli & VIII & 5.7 & 14 \\
5 & 23.03 .1969 & $23: 08$ & Demirci-Manisa & VIII & 5.9 & - \\
6 & 28.03 .1969 & $03: 48$ & Alasehir-Manisa & VIII & 6.5 & 53 \\
7 & 28.03 .1970 & $23: 02$ & Gediz & IX & 7.2 & 1086 \\
8 & 19.04 .1970 & $15: 29$ & Gediz & VIII & 5.8 & - \\
9 & 23.04 .1970 & $11: 01$ & Demirci-Manisa & VIII & 5.6 & 57 \\
10 & 12.05 .1971 & $08: 25$ & Burdur & VIII & 5.9 & 90 \\
11 & 01.10 .1995 & $17: 57$ & Dinar-Afyon & VIII & 6.1 & \\
\hline
\end{tabular}

acterizing the fault plane (Pasyanos et al., 1996) and also can aid earthquake early warning systems by providing stable estimates of the regional source parameters (Böse et al., 2009). Furthermore, the accurate estimation of hypocenters, fault plane systems, and the orientation of the $P$ and $T$ axes derived from focal mechanism, are very useful in understanding the regional tectonics and kinematics in a region (Holt et al., 1991). Therefore, the present study aims to determine the fault mechanisms in the Denizli Graben System and to define the fault mechanism in relation to the regional tectonics, as well as to provide a stable regional source parameters' database. The installation of broadband stations since 2004 by the Kandilli Observatory and the Earthquake Research Insitute (KOERI) makes it possible to analyze the small to moderate earthquakes that occur at local and regional distances, using regional body-waveform analysis. For this purpose, the focal mechanisms of the 20 earthquakes $(M \geq 3.1)$ which occurred in the Denizli Basin from 2004 to 2009, and a determination of the present-day stress field, are presented in this study. Within this scope, both regionally recorded seismic waves and first motion polarities were used to extract information about the earthquake sources, in particular, depth, seismic moment and focal mechanism. For the determination of fault plane mechanisms, different methodologies have been used. First, the well-known search method of Snoke et al. (1984) was applied on the $P$-wave first motion data to 20 earthquakes. Then, the waveform matching method of Dreger and Romanowicz (1994), and Pasyanos et al. (1996), was used for suitable earthquakes. A formal inversion method (the WinTensor program of Delvaux and Sperner, 2003) was performed in order to determine the present-day stress field. 
The extension rate was calculated by Brune (1968) using the seismic moments obtained from regional body-wave inversion analysis. Earthquake fault mechanisms, present-day stress fields and extension rates enhance our understanding of the seismotectonics within the Denizli Graben System.

\section{Tectonic Settings}

The Denizli Graben System is located in an area where three major E-W Grabens (Gediz, Küçükmenderes and Büyükmenderes) approach at their eastern ends and the NE-SW trending Çivril, and the E-W to NE-SW Acıgöl, Grabens join. The Denizli Graben System is defined as a NW-SE trending basin about $50 \mathrm{~km}$ in length and 7-28 $\mathrm{km}$ in width and an actively growing rift system and has been studied in detail by Westaway (1993), Sözbilir (2002), Koçyiğit (2005), Westaway et al. (2005) and Kaymakçı (2006), (Fig. 1).

The Denizli Graben System developed upon preOligocene metamorphic rocks both the Menderes Massif, Lycian Nappes and an Oligocene-Lower Miocene molassic sequence (Sözbilir, 1997, 2002). According to Westaway (1993), the development of the Denizli Basin started 14 Ma years ago and the total slip is between 1050 and $2080 \mathrm{~m}$, and the estimated average slip rate is $0.14-0.15$ $\mathrm{mm} /$ year (Koçyiğit, 2005). The initial form of graben (7 $\mathrm{km}$ to $28 \mathrm{~km}$ ) is much wider than the present-day form ( $3 \mathrm{~km}$ to $14 \mathrm{~km}$ ) and has been uplifted and dissected into several small-scale sub-horsts and sub-grabens (Koçyiğit, 2005). The Denizli Graben System is subdivided into four segments of different sizes and orientations: (a) the NW trending Buldan-Pamukkale Segment comprises the bulk of the modern graben system; (b) the E-W trending Honaz Segment; (c) the NE trending Kocabaş Segment, and (d) the E-W trending Kaklık Segment (Koçyiğit, 2005). The Denizli Graben System has many normal faults of varying lengths $(0.5 \mathrm{~km}$ to $40 \mathrm{~km})$ : Babadağ, Honaz, Aşağıdağdere, Küçükmalıdağ, Pamukkale, Buharkent, Kaleköy, Buldan, Çukurköy fault zones and faults (Koçyiğit, 2005).

Babadağ Fault Zone: The Babadağ Fault zone is the southern incipient and about $3 \mathrm{~km}$ wide and $66 \mathrm{~km}$ long, NW trending and graben-facing range-front normal fault zone and has played an important role in both the earlier, and the present day, developing history of the Denizli Graben System. It contains two major faults, and also a number of short (0.5-12 km) closely-spaced synthetic normal faults (Koçyiğit, 2005). The Babadağ Fault Zone is still active and has produced 1703, 1717 and 1744 historical period earthquakes (Ergin et al., 1967; Soysal et al., 1981; Ambraseys and Finkel, 1995) and generated the 19 August, $1976\left(M_{\mathrm{L}}=5.0\right)$ earthquake (Ateş and Bayülke, 1982).

Honaz Fault Zone: This is another southern incipient margin-bounding fault zone in the vicinity of Honaz County. The Honaz Fault Zone is about $2 \mathrm{~km}$ wide and 13.5 $\mathrm{km}$ long, E-W trending and graben-facing step-like normal fault zone. It consists of four parallel north dipping major fault segments and five synthetic fault segments (Koçyiğit, 2005). Koçyiğit (2005) indicates that the major segment of the Honaz Fault Zone is an oblique-slip normal fault dipping an average of $56^{\circ} \mathrm{NNE}$, with a minor dextral strike-slip component. The Honaz Fault Zone is seismically active and generated the 1703 earthquake during the historical period (before 1900 AD) (Ergin et al., 1967; Soysal et al., 1981; Ambraseys and Finkel, 1995).

Aşă̆ıdăgdere Fault Zone: The Aşağıdağdere fault zone located at the southernmost edge of the graben is about $5 \mathrm{~km}$ long. It contains four NE-SW trending short $(0.5-5 \mathrm{~km})$, and closely-spaced, fault segments. Their stereographic plot shows that the fault segment is an oblique-slip normal fault (Koçyiğit, 2005).

Küçükmalıdă Fault Zone: This is a $2-3 \mathrm{~km}$ wide and 10 $\mathrm{km}$ long, NW trending fault zone located at the northeastern edge of the Denizli Graben System. It consists of three NWSE trending faults: Küçükmalı (4-5 km long), Düzçalı (0.5$8 \mathrm{~km}$ long) and Sarıkaya (6-7 km long). The 13 June, 1965 $\left(M_{\mathrm{L}}=5.3\right)$ Kaklık (Denizli) earthquake was located in the Küçükmalıdağ Fault Zone (Koçyiğit, 2005).

Pamukkale Fault Zone: The fault zone is the northern margin-bounding fault zone of the Denizli Fault System. The fault is about $4 \mathrm{~km}$ wide and $53 \mathrm{~km}$ long, NW trending (excluding a southernmost, $7 \mathrm{~km}$ long, E-W trending segment) with a normal fault mechanism. It contains two major and several small to moderate faults (Koçyiğit, 2005). A moderate earthquake occurred in the fault zone on 21 April, $2000\left(M_{\mathrm{L}}=5.2\right)$ (Özalaybey et al., 2000; Horasan et al., 2002).

Kaleköy Fault Zone: The Kaleköy fault zone is described by Koçyiğit (2005) as a NW trending normal fault zone, 2-8 $\mathrm{km}$ wide and $34 \mathrm{~km}$ long. It consists of four fault segments. Özalaybey et al. (2000) and Koçyiğit (2005) indicated that most of the shallow-focus earthquake epicenters were concentrated in the northern hanging-wall block of the Kaleköy fault zone. Their focal-mechanism solutions indicated that the kinds of faults varied from dip-slip to oblique-slip normal faults.

\section{Source Parameters}

The number of digital broadband stations operated by the National Earthquake Monitoring Center of The Kandilli Observatory and Earthquake Research Institute (NEMCKOERI) has been increasing since the devastating Kocaeli earthquake of August 17, 1999, in Turkey. Therefore, nowadays it is possible to obtain reliable fault plane solutions for any area of Turkey using waveform inversion techniques. Digital data sets have been available since 2004 and accessible via the internet provided by the NEMC-KOERI data center. The data used in this study were obtained from NEMC-KOERI. There were 36 earthquakes in the time period of 2004-2009. The polarity method was used to compute the fps of 20 earthquakes, additionally the inversion method could be applied to ten of them. In Table 2, only one result for each is given, but in the appendix both results are shown for the ten earthquakes. All events were located in the upper brittle crust and the depths of all events are less than $10 \mathrm{~km}$, located at $6-8 \mathrm{~km}$.

\subsection{Fault plane solution ( $P$-wave first motion)}

The fault plane solutions were calculated by utilizing $P$-polarities on vertical component seismograms running the focmec programs (Snoke et al., 1984) for the analyzed earthquakes. All available polarities from national seismic stations were carefully read. The number of stations with 


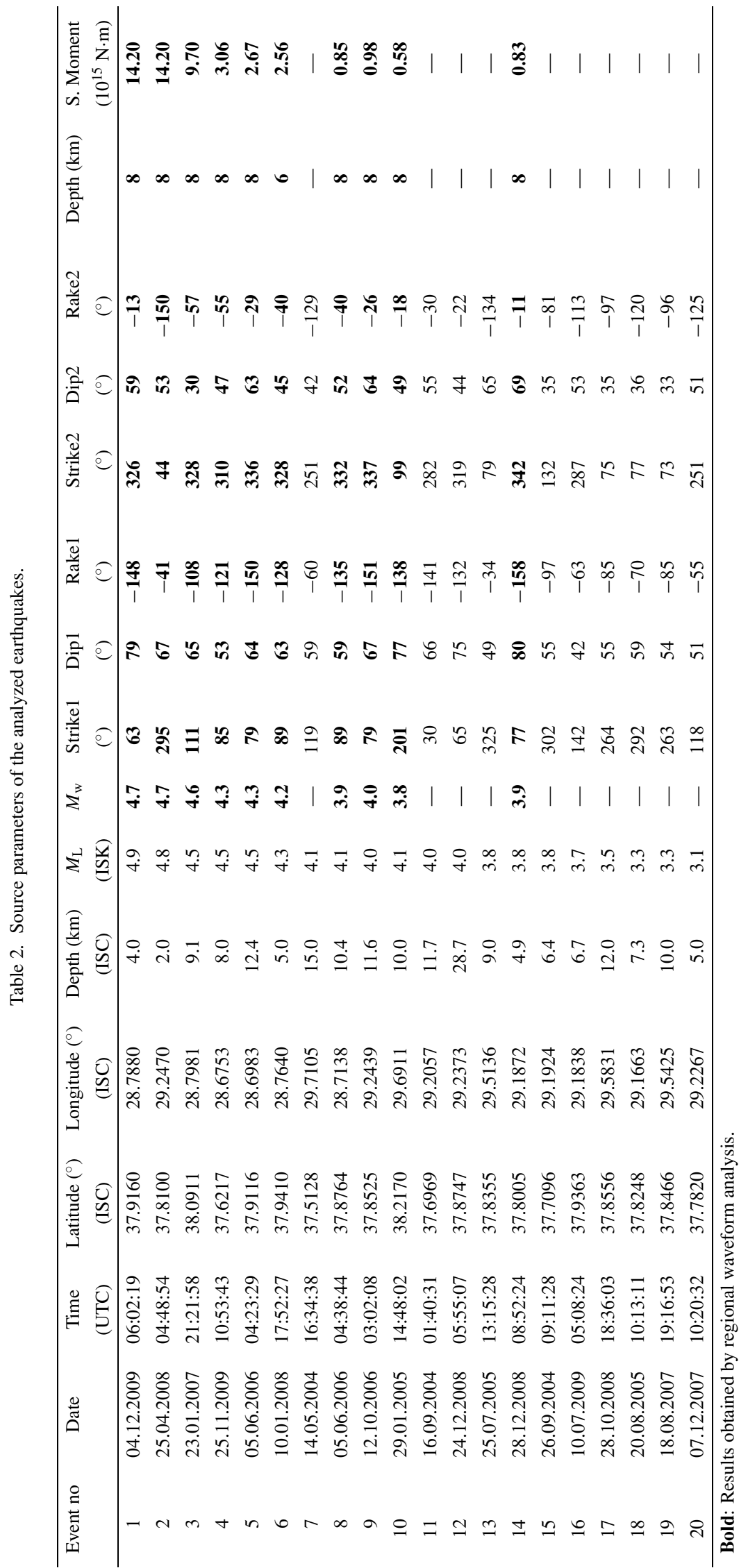




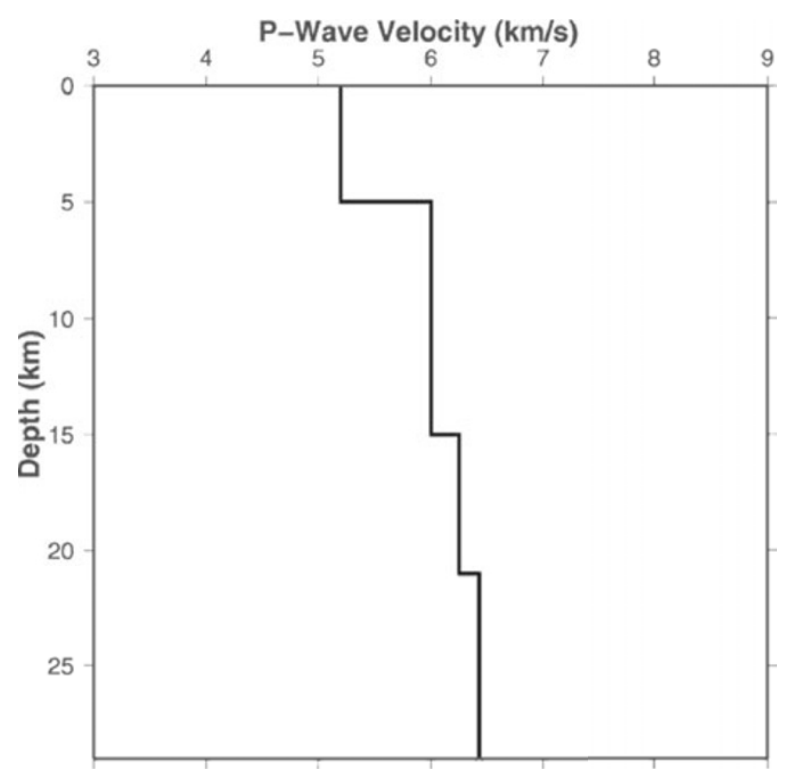

Fig. 2. Velocity Model for the Denizli Graben System, the depth of Moho is $29 \mathrm{~km}$ (modified from Akyol et al., 2006).

unambiguous first arrival polarities varies from earthquake to earthquake, but events with fewer than 10 clear polarity readings were discarded, as were those with ambiguous polarities. The $P$-waves were converted to displacement in order to see the $P$-wave onsets better due to low $\mathrm{S} / \mathrm{N}$ ratio. Assuming the double-couple model for the seismic point source, $P$-polarities on displacement seismograms were then read. Polarity errors could be caused by a low $\mathrm{S} / \mathrm{N}$ ratio at stations near nodal planes, so called 'mislocations', or structural heterogeneity, biasing calculation of azimuth and take off angle, and aliasing effects (Scherbaum, 1994). However, no polarity error was allowed in the solutions. Events with multiple acceptable solutions, indicating different mechanisms, or with faulting parameters' uncertainties exceeding $20^{\circ}$, are not reported in this study.

\subsection{Time domain moment tensor analysis}

The theory of moment tensor analysis involves fitting theoretical waveforms with observed broadband waveforms and inverting for the moment tensor elements. Inversion for the seismic moment tensor was performed following the least squares approach of Dreger and Helmberger (1993), and Dreger (2003), who have demonstrated that the method is reliable for events with local magnitudes as low as 3.5. The body waveform modeling technique is described by Dreger and Helmberger (1993). This method utilizes threecomponent body waveforms recorded at local (less than $100 \mathrm{~km}$ ) and regional (100 to $1000 \mathrm{~km}$ ) distances to determine the seismic moment tensor. This procedure is designed to obtain reliable solutions using a minimal number of stations. Data from a single three-component station would be sufficient, but a few stations with some azimuthal coverage generally could give more reliable results. Typically, only two or three three-component broadband stations are required to obtain a unique solution (Dreger and Helmberger, 1993). Indeed, several regional moment tensor inversion studies were performed with a few stations and some azimuthal coverage (Dreger and Helmberger, 1991, 1993; Romanowicz et al., 1993; Gee et al., 1996; Shomali and Slunga, 2000).

The source time function is assumed to be a Dirac delta function since the events used in this study generally have source durations of 2-3 s $\left(M_{\mathrm{L}}<5\right)$, and seismograms in the passband of 20-50 s are used (Dreger, 2003).

The source depth is found iteratively by finding the solution that yields the largest variance reduction. The results of the moment tensor inversion are generally not very sensitive to location errors. Dreger and Helmberger (1993), and also Pasyanos et al. (1996), showed that errors of up to $15 \mathrm{~km}$ in epicenter locations are less important at a distance range of $50-400 \mathrm{~km}$.

Green's functions were calculated following a modified Haskell algorithm in the frequency-wavenumber domain (Saikia, 1994). The formulation uses the three basic focal mechanisms: normal, reverse and pure strike-slip (Langston, 1981; Herrmann and Wang, 1985). Far-field and near-field terms are both considered in this algorithm. The sampling rate was fixed at $2 \mathrm{~Hz}$. The most important step for the regional moment tensor analysis is to develop an accurate 1-D velocity model due to the calculation of correct Green's functions at regional distances. The velocity model of Akyol et al. (2006) was used as an initial model. A trial and error method that gave the best fit and higher variance reduction (VR) between the observed and calculated seismograms was used to adjust the final velocity model (Fig. 2).

The quality of the inversion can be controlled by different functions. Dreger et al. $(1995,2000)$ indicated that output data variance and also variance reduction that assumes a value of 100 when observed and calculated seismograms are identical. Furthermore, the resulting tensor can be decomposed into a double-couple (DC) and a Compensated Linear Vector Dipole (CLVD). The percentage of DC (PDC) (Jost and Herrmann, 1989) shows how well the model complies with a double-couple source. Note that any CLVD contribution is an artifact of the present inversion scheme and indicates the influences of structural complexi- 
ties that are not considered in the calculation of the Green's functions, source complexities, location errors (depth), etc. The obtained source parameters are given in Table 2 .

3.2.1 Data processing Data from broadband stations accessible via the internet from the KOERI data center at (http://barbar.koeri.boun.edu.tr/sismo/zKDRS/ zzTRwavType.asp) were selected at a regional distance. Recently, station coverage has increased significantly in this area. The three-component broadband seismograms were cut into predefined time segments and transformed into Seismic Analysis Code (SAC) format and converted to ground displacement using poles and zeros. Before integration using the trapezoidal rule (within SAC), a linear trend was removed, and the data was tapered (5-10\% of window length using the Hanning window), and rotated into a ray coordinate system. Frequency bands used are dependent on magnitude (Dreger et al., 1995). Accordingly, $3.5<M_{\mathrm{L}}<4.0$ correspond to the frequency band $0.02-0.1 \mathrm{~Hz}$; and $4.0<M_{\mathrm{L}}<5.0$ to $0.02-0.05 \mathrm{~Hz}$. A second-order Butterworth bandpass filter was applied in a forward and backward direction to prevent phase shift. Data were resampled $(2 \mathrm{~Hz})$. Finally, synthetic data had to be time corrected (zero-offset) to compensate for errors in the overall velocity model, source depth, etc.

\subsection{Stress inversion}

Fault plane solutions of earthquakes occurring in the brittle part of the crust are expressions of the present regional stress field, and how these stresses act on existing structures in the crust. Thereby, the fault plane solutions obtained from the inversion method are useful to define in the tectonic stress field and enable implications regarding dynamic processes and tectonic evolution. Especially, for the middle and lower crust, where borehole measurements are not possible, the analysis of the focal mechanism is the only tool for in-situ stress measurements.

To study the present-day stress field for the Denizli Graben, a new Win-Tensor program, the Windows version of the TENSOR program (Delvaux, 1993) developed by D. Delvaux, according to the procedure described in Delvaux and Sperner (2003) and using a Quality Ranking scheme as in the World Stress Map project (Sperner et al., 2003), was used for formal stress inversions of the given focal mechanism. The Win-Tensor program runs were based on two major assumptions for the studied region: (a) the stress field is uniform and invariant in space and time; and (b) earthquake slip $d$ occurs in the direction of maximum shear stress $\tau$ (Bott, 1959). The angle between the calculated stress $\tau$ and the slip vector $d$ is the misfit angle $\alpha$. Thus, the corresponding misfit function to be minimized for each earthquake $i$ is the misfit angle $\alpha$ :

$$
f(i)=a(i) .
$$

The orientation of the three orthogonal principal stress axes $\sigma_{1}, \sigma_{2}$ and $\sigma_{3}$ (where $\sigma_{1} \geq \sigma_{2} \geq \sigma_{3}$ ) and the stress ratio $R$ :

$$
R=\left(\sigma_{2}-\sigma_{3}\right) /\left(\sigma_{1}-\sigma_{3}\right)
$$

which expresses the magnitude of $\sigma_{2}$ relative to the magnitudes of $\sigma_{1}$ and $\sigma_{3}$.

The main stress regime is a function of the orientation of the principal axes and the shape of the stress ellipsoid: ex- tensional when $\sigma_{1}$ is vertical, strike-slip when $\sigma_{2}$ is vertical, and compressional when $\sigma_{3}$ is vertical. For each of these three regimes, the value of the stress ratio $R$ fluctuates between 0 and 1. Therefore, Delvaux et al. (1997) introduce the stress regime index $R^{\prime}$ :

- $R^{\prime}=R$ when $\sigma_{1}$ is vertical (extensional stress regime)

- $R^{\prime}=2-R$ when $\sigma_{2}$ is vertical (strike-slip stress regime)

- $R^{\prime}=2+R$ when $\sigma_{3}$ is vertical (compressional stress regime)

$R^{\prime}$ defines the stress regime on a continuous scale from 0 (radial extension) to 3 (radial compression), in detail from 0 to 1 for normal faulting regimes ( $\sigma_{1}$ sub-vertical), from 1 to 2 for strike-slip regimes ( $\sigma_{2}$ sub-vertical), and from 2 to 3 for thrust faulting regimes ( $\sigma_{3}$ sub-vertical).

The data were processed interactively by the TENSOR program. First using the "Right Dihedron Method", a graphical method for the determination of possible orientations of $\sigma_{1}$ and $\sigma_{3}$, which are independent of the choice of the nodal planes (Angelier and Mechler, 1977). The initial result is used as a starting point for the iterative grid-search "Rotational Optimisation" procedure using the misfit function F5 in the TENSOR program package (described as $\mathrm{f} 3$ in Delvaux and Sperner, 2003). It minimizes the misfit angle $\alpha$ (Eq. (1)) using the stress tensor. It also favours high shear stress magnitudes $|\tau(i)|$ and low normal stress magnitudes $|v(i)|$ on the plane in order to promote slip. It contains three terms and is implemented in a way that ranges from 0 (optimal misfit) to 360 and is independent of the ratio of $\sigma_{3} / \sigma_{1}$. The first term that minimizes $\alpha$ is based on function S4 of Angelier (1991):

$$
f(i)=\sin ^{2}(\alpha(i) / 2)
$$

and is dominant over two other terms (see Delvaux and Sperner, 2003 for details).

First, both nodal planes for each earthquake were inverted to a stress tensor. Then the plane that is best explained by the stress tensor is selected from the two nodal planes (smaller value of function F5 in TENSOR or f3 in Delvaux and Sperner, 2003) and considered as the actual fault (or focal) plane. After this separation, the final inversion then includes only focal planes that are best fitted by a uniform stress field (Gephart and Forsyth, 1984). The graphical output of the stress tensor in an equal-area projection allows the evaluation of the overall quality of the result.

\subsection{Slip rate}

The Brune (1968) method was used to calculate the slip rates for the Denizli Graben System. The total average displacement for the whole length of the fault can be calculated by using the following equation:

$$
\Sigma\langle\langle u\rangle\rangle=\frac{1}{\mu A_{0}} \Sigma M_{0}
$$

where $u$ is the total average displacement (m), $\mu$ is the rigidity $\left(\mathrm{N} \mathrm{m}^{-2}\right), A_{0}$ is the fault $\left(\mathrm{m}^{2}\right)$ area and $M_{0}$ is the seismic moment $(\mathrm{N} \mathrm{m})$. The seismic moments for the earthquakes are calculated from regional waveform inversion. 
a)

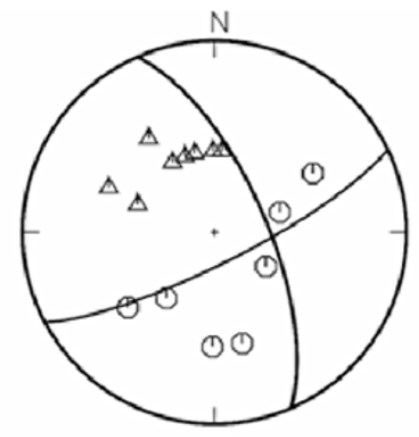

d)

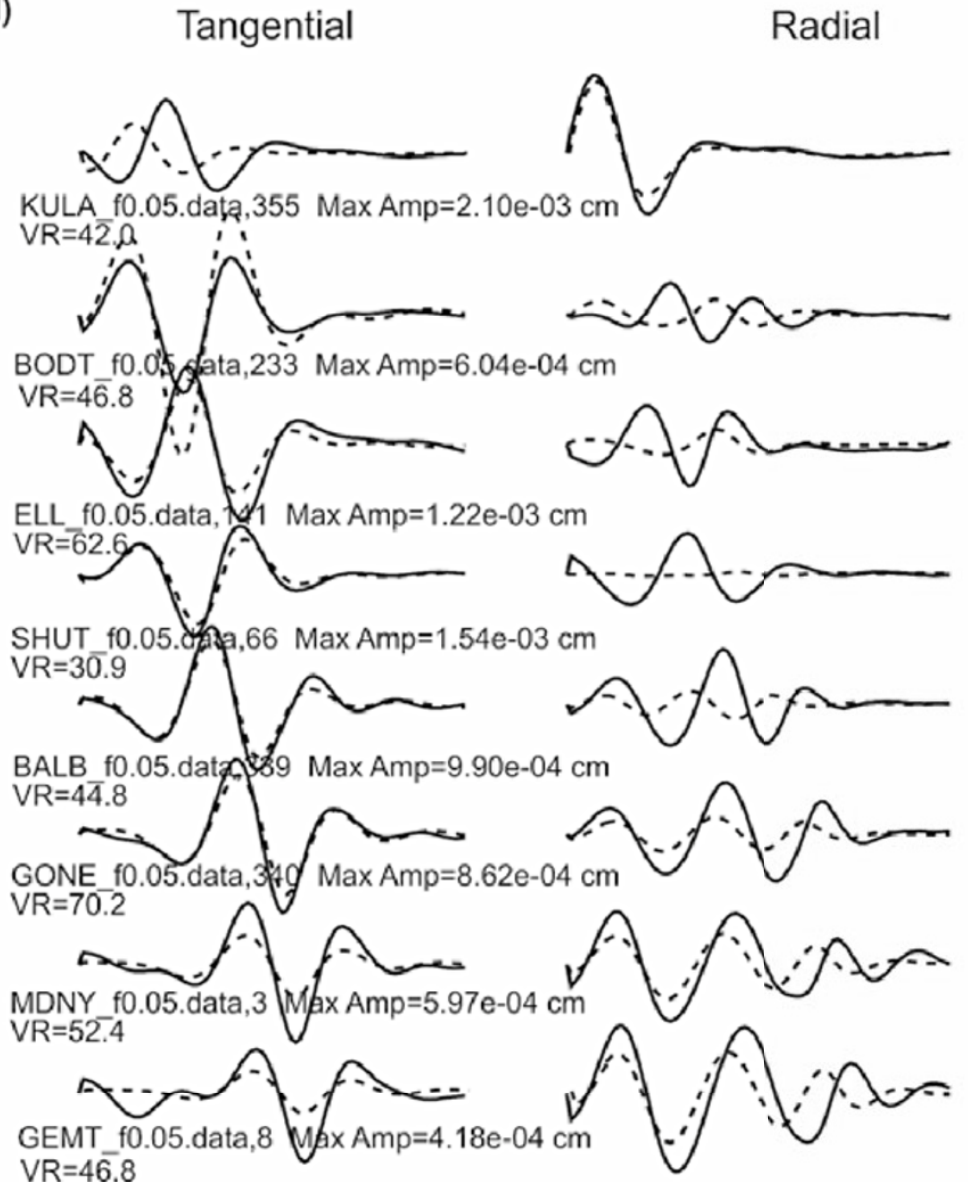

b)

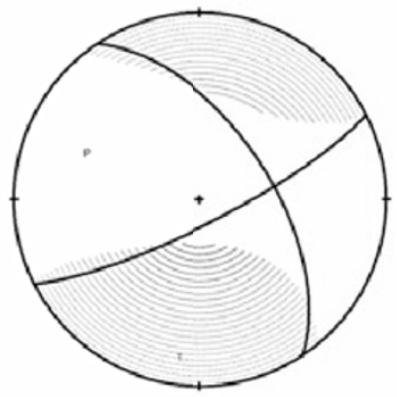

Radial
Strike $=63 ; 326$

Rake $=-148 ;-13$

Dip $=79 ; 59$

Mo $=1.42 \mathrm{e}+23$

$M w=4.7$

Percent DC=45

Percent CLVD $=55$

Percent $I S O=0$

Variance $=6.03 e-08$

Var. Red $=6.35 \mathrm{e}+01$

RES/Pdc $=1.71 \mathrm{e}-09$

\section{Vertical}
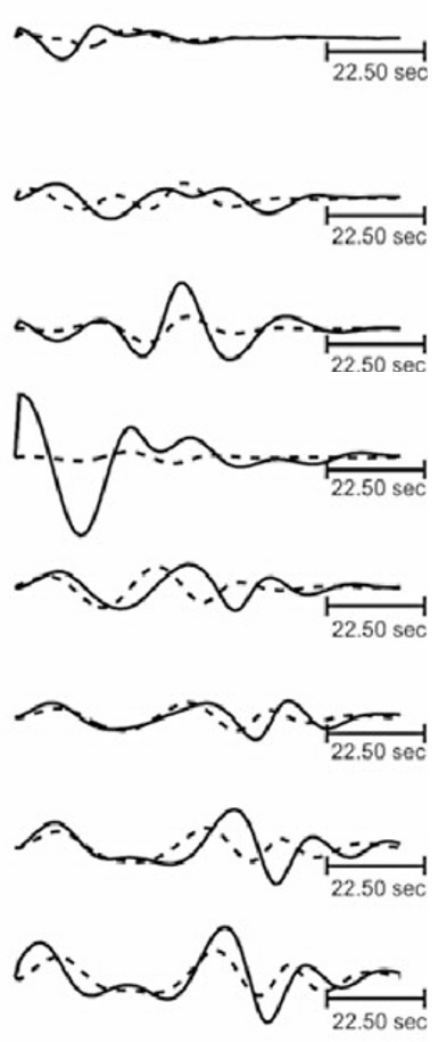

Fig. 3. Inversion results for the first event in Table 2. (a) First motion solutions. (b) Moment tensor analysis result. (c) Inversion details. (d) Waveform fitting, dashed: calculated, solid: observed seismograms. Letters and numbers below seismograms indicate station code, filtered data, azimuth, maximum amplitude, respectively.

\section{Results and Discussion}

Figure 3 gives an example of the inversion result details for event no. 1 (Table 2). This is the largest event $\left(M_{\mathrm{w}}=4.7\right)$ among the analyzed earthquakes. Data from 8 of the available 10 stations in a distance ranging between 90 and $300 \mathrm{~km}$ were used for inversion. Data of the other two stations were not used due to their low $\mathrm{S} / \mathrm{N}$ ratio. The observed and calculated seismograms were band-pass filtered at $0.02-0.05 \mathrm{~Hz}$. The $\mathrm{S} / \mathrm{N}$ ratio of event 1 is generally good for frequencies above $0.02 \mathrm{~Hz}$ (Dreger and Helmberger, 1993). Variance reduction (VR) is $63.5 \%$ and the misfit between the observed and calculated seismograms is good and is probably decreased by the noise on the horizontal components. The source depth by the inversion (8 $\mathrm{km}$ ) is slightly larger than the International Seismological
Centre (ISC) (4 km) solutions (ISC, 2010), but smaller than the Global Centroid Moment Tensor Project (GCMT) (12.2 $\mathrm{km})$ and the Istituto Nazionale di Geofisica e Vulcanologia (INGV) solutions $(14 \mathrm{~km})$. A moment magnitude was obtained of $M_{\mathrm{w}}=4.7$, which is less than, but comparable with, the GCMT $\left(M_{\mathrm{w}}=5.0\right)$ and the $\operatorname{INGV}\left(M_{\mathrm{w}}=4.9\right)$ solutions. The focal mechanism indicated normal faulting with a large strike-slip component with the $T$-axis trending NNE-SSW and the $P$-axis nearly NW-SE, which is consistent with the tectonics of the region. The solution of the first motion polarities presented a good agreement with the focal mechanism obtained by moment tensor analysis. The moment tensor analysis and solutions of the first motion polarities are given in Appendix A. In general, the regional moment tensor analysis results indicate a high CLVD 


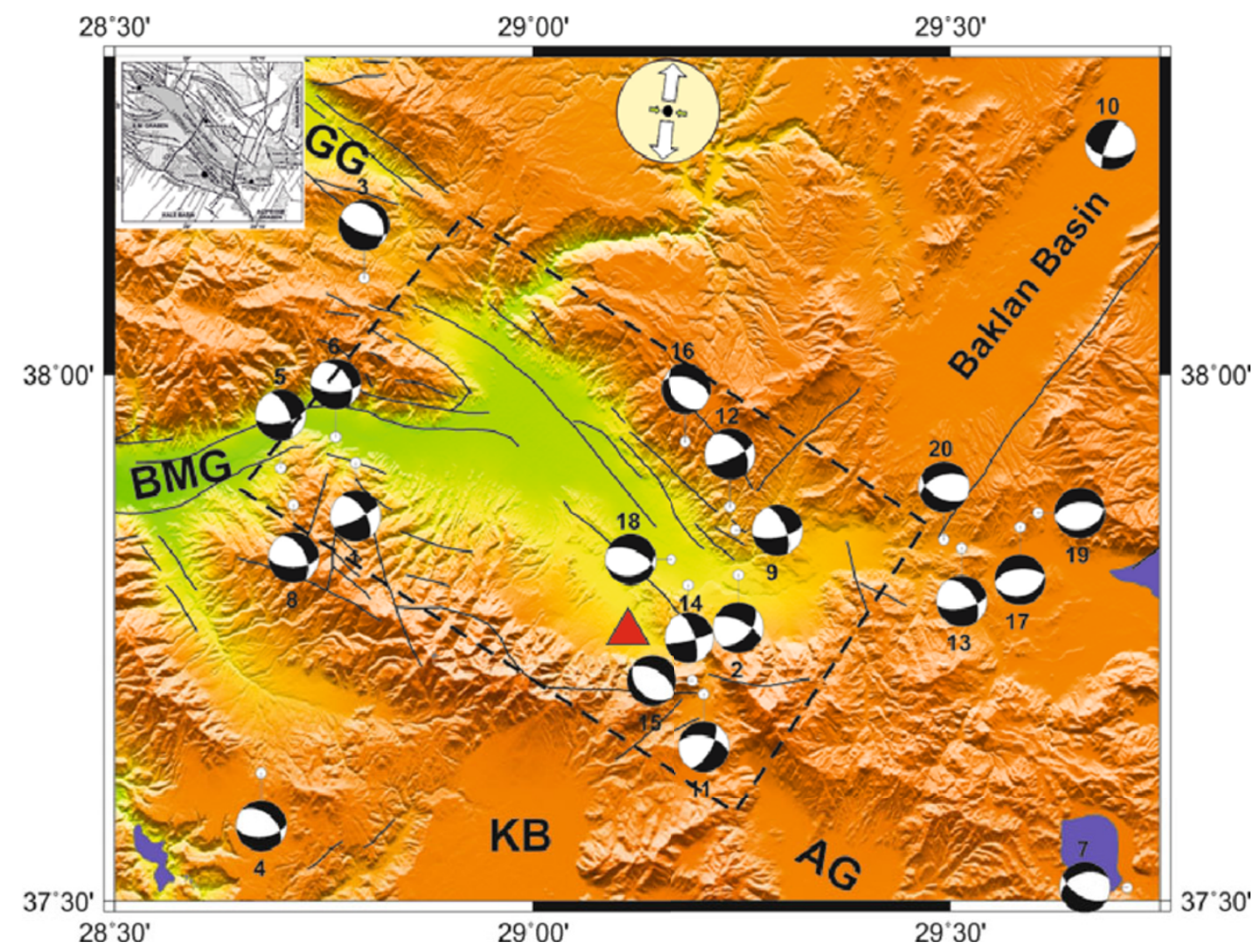

Fig. 4. Focal mechanisms of analyzed earthquakes in the Denizli Graben System. The numbers above/below the beach balls show the event number in Table 2. The red triangle marks the epicenter of the June 13, 1965, earthquake epicenter. Dashed area indicates the approximate area of the Denizli Graben which was used for slip rate calculation. White and black arrows on the top of the figure represent $T$ and $P$ axes directions, respectively. BMG: Büyük Menderes Graben, GG: Gediz Graben, AG: Acıgöl Basin, KB: Kale Basin.

value (Appendix A). This could be due to oblique, nonparallel layers, strong heterogeneities, anisotropy (usually not so strong), or other unconsidered effects and errors. Additionally, the large CLVD values due to hydrothermal effects in the Denizli region, especially at the triple junction of the Büyük Menderes fault and Gediz/Pamukkale fault in the north of the Denizli Basin.

Figure 4 summarizes the resulting fault plane solutions for all earthquakes investigated in this study (Table 2). Most events are characterized by near horizontal $T$-axes oriented essentially NNE-SSW, i.e., events 1, 5, 6, 8, 9, 12, 13, 14,15 . The focal mechanisms reflect that the extensional regime is dominant in the NE-SW direction in the Denizli Graben. Four events which occurred in adjacent grabens (events 3, 4, 7 and 10) also show a normal faulting mechanism.

The analyzed earthquakes were characterized by normal faulting mechanisms with large dip angles and small strikeslip components. Çakır (1999) indicates that the Pamukkale Fault Zone displays a subordinate component of sinistral strike-slip in addition to a dominant component of normal dip-slip. Also, recent work of Noten Van et al. (2013) has concluded that some normal faults were reactivated causing a left-lateral deformation in a transient strike-slip stress field with NE-SW orientations. The focal mechanism of the earthquakes which occurred around the PFZ in Fig. 4, in a NE-SW faulting direction have a small amount of left- lateral strike-slip component.

Şengör (1987) has pointed out that all extensional earthquakes in Western Anatolia, and in the Aegean, occur at depths not exceeding $10 \mathrm{~km}$. Akyol et al. (2006) considered the depth distribution of the well located earthquakes and they showed that the predominant depth of seismicity is around $9-10 \mathrm{~km}$. The results indicate that the depths of the analyzed earthquakes, defined by regional moment tensor analysis, are located in the range of $6-8 \mathrm{~km}$.

Figure 5 shows the diagrams of focal mechanism inversions of the Denizli Graben earthquakes. Four events (i.e. events 3, 4, 7, 10 in Table 2) occurred outside the graben, so they were not included in the stress inversion. For the focal mechanism, the kinematic $p, b$ and $t$ axes (Table 3) are used to infer the orientations of the horizontal principal stress axes $\sigma_{1}, \sigma_{2}$ and $\sigma_{3}$, respectively (Zoback, 1992). The stress inversion results reveal that the orientations of the principal stress axes are nearly vertical for $\sigma_{1}$ and nearly horizontal for $\sigma_{2}$ and $\sigma_{3}$. Axes orientations are computed to be $62^{\circ} / 277^{\circ}, 28^{\circ} / 100^{\circ}$, and $1^{\circ} / 9^{\circ}$ (dip/azimuth direction) for $\sigma_{1}, \sigma_{2}$ and $\sigma_{3}$. The stress inversion of the studied earthquake focal mechanism data shows that the present-day stress field is characterized by a pure extensional regime $\left(R^{\prime}=0.74\right.$, Delvaux et al. (1997)) and a horizontal direction of extension at $\mathrm{N} 9^{\circ} \mathrm{E}$, close to $\mathrm{N}-\mathrm{S}$. The $T$ axes indicate that the Denizli Graben is opening in the direction NE-SW. This result indicates good agreement with the 

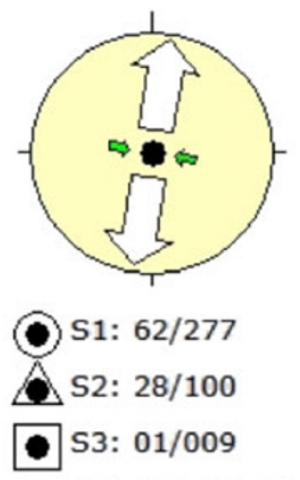

$R: 0.74$ F5: 17.49 $\mathrm{QRfm}: \mathrm{B}$

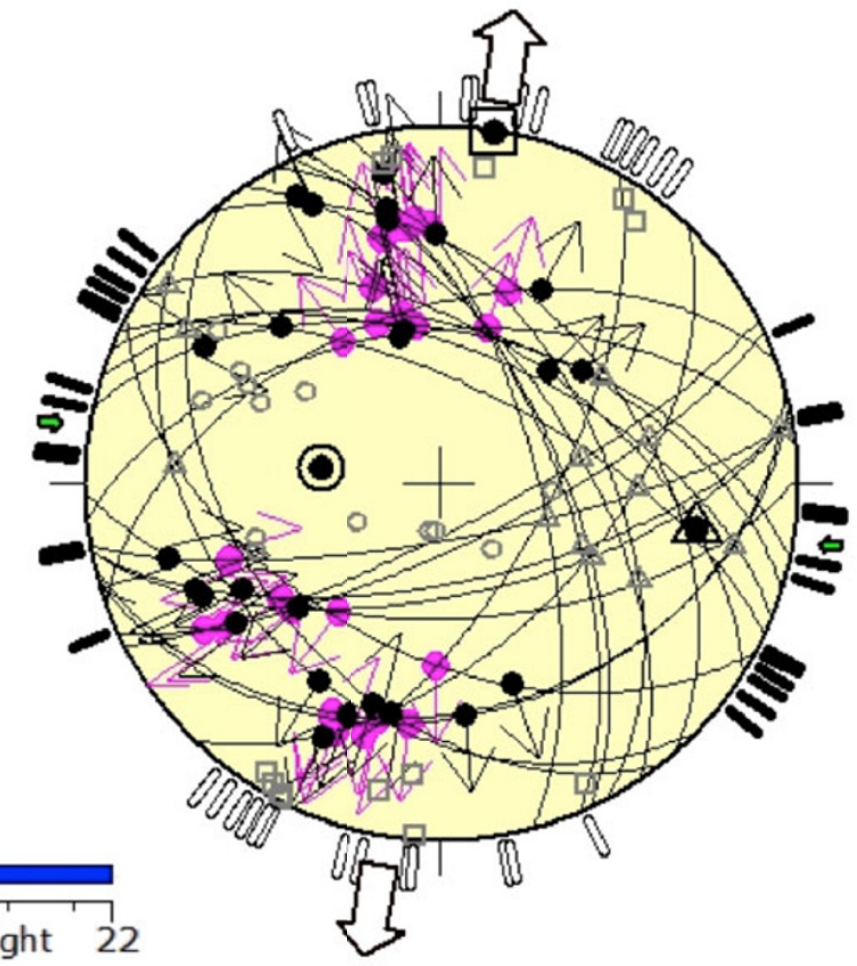

Fig. 5. Stress inversion result of the selected focal planes projected to the lower hemisphere (Schmidt stereographic projection). The histogram represents the distribution of the misfit function F5, weighted arithmetically according to magnitudes.

Table 3. $P$ and $T$ axes of the analyzed earthquakes.

\begin{tabular}{rrrrr}
\hline Event no & \multicolumn{3}{c}{$P$} & \multicolumn{2}{c}{$T$} \\
\cline { 2 - 5 } & Azimuth $\left(^{\circ}\right)$ & Plunge $\left(^{\circ}\right)$ & Azimuth $\left(^{\circ}\right)$ & Plunge $\left(^{\circ}\right)$ \\
\hline 1 & 289 & 30 & 191 & 13 \\
3 & 254 & 45 & 352 & 9 \\
4 & 350 & 65 & 214 & 18 \\
5 & 294 & 65 & 196 & 3 \\
6 & 297 & 39 & 207 & 1 \\
7 & 310 & 55 & 205 & 10 \\
8 & 80 & 63 & 188 & 9 \\
9 & 304 & 52 & 209 & 4 \\
10 & 299 & 36 & 207 & 2 \\
11 & 69 & 38 & 324 & 7 \\
12 & 250 & 44 & 154 & 19 \\
13 & 294 & 44 & 185 & 9 \\
14 & 300 & 49 & 199 & 6 \\
15 & 304 & 25 & 211 & 10 \\
16 & 186 & 79 & 37 & 6 \\
17 & 141 & 71 & 33 & 10 \\
18 & 194 & 79 & 350 & 12 \\
19 & 245 & 69 & 850 & 10 \\
20 & 193 & 79 & 184 & \\
\hline
\end{tabular}

studies of Kaymakçı (2006) and Noten Van et al. (2013). Kaymakç1 (2006) indicated that both the NE-SW and NWSE extension are presently active and they may frequently interchange in time and place in the Denizli Graben, including the Baklan, Acıgöl, and Burdur Basins.

The slip rate was calculated by using the obtained seismic moment values listed in Table 2 for the time period 20042009, by using Eq. (4). According to Kaymakçı (2006), the size of the Denizli Graben is approximately $50 \mathrm{~km}$ long and $25 \mathrm{~km}$ wide. Using the depths of the analyzed earthquakes and considering other studies (Şengör, 1987; Akyol et al., 2006), the thickness of the seismogenic zone is taken to be $10 \mathrm{~km}$. Then, the fault area is calculated by length multiplied by thickness. The events 3, 4, 7 and 10 (Table 2) occurred outside the graben, so they were excluded from the slip rate calculation. The total seismic moment is 
calculated to be $\Sigma M_{0}=3.629 \times 10^{16} \mathrm{~N} \mathrm{~m}$, and the total area is $A_{0}=5.0 \times 10^{8} \mathrm{~m}^{2}$, and with the rigidity taken to be $\mu=3.3 \times 10^{10} \mathrm{~N} \mathrm{~m}^{-2}$, the total slip was found to be $\Sigma u=2.2 \times 10^{-3} \mathrm{~m}$. The slip rate for the period 2004-2009 was calculated to be about $0.37 \mathrm{~mm} /$ year for the whole basin, which is larger than the value of 0.14 $0.15 \mathrm{~mm} /$ year calculated by Koçyiğit (2005), but comparable with the studies of Westaway (1993) and Altunel and Karabacak (2005). Westaway (1993) found the total extension of the normal faults to be $0.5 \mathrm{~mm} /$ year for the western end of the basin, $0.3 \mathrm{~mm} /$ year for the center of the basin and $0.2 \mathrm{~mm} /$ year for the eastern end of the basin. Altunel and Karabacak (2005) calculated these rates as $0.6 \mathrm{~mm} / \mathrm{year}$, $0.39 \mathrm{~mm} /$ year and $0.23 \mathrm{~mm} /$ year, respectively, for the same segments.

The magnitudes of the analyzed earthquakes are less than five, and it is well known that most of the accumulated seismic moment is released by larger earthquakes. As seen in Table 1, numerous large earthquakes have occurred in the southwest of Turkey. However, three earthquakes- the 13 June, 1965, earthquake $\left(M_{\mathrm{S}}=5.7, m_{\mathrm{b}}=5.1\right)$ in the Küçükmalıdağ Fault Zone, the 19 August, 1976, earthquake $\left(m_{\mathrm{b}}=5.0\right)$ in the Babadag Fault Zone, and the 21 April, 2000, earthquake $\left(m_{\mathrm{b}}=4.8\right)$ in the Pamukkale Fault Zone (Ateş and Bayülke, 1982; Özalaybey et al., 2000; Horasan et al., 2002; Koçyiğit, 2005)—occurred in the study area.

Gutenberg and Richter (1956) have indicated that shocks of the largest magnitude record with surface wave relatively large compared with the body waves shocks of magnitudes below 7 , show relatively small surface waves when recorded at teleseismic distances. Many long-period instruments do not record such shocks clearly, which makes the determination of magnitude from the data of distant stations difficult. Short-period instruments in such cases may show a measurable $P$; the absence of recorded surface waves is then sometimes misinterpreted as evidence for a deep focus. Thus, the relationship between the two magnitudes established by Gutenberg and Richter (1956) is:

$$
m_{\mathrm{b}}=0.63 M_{\mathrm{S}}+2.5 \text {. }
$$

This equation indicates that the magnitudes of small earthquakes $(M<6.5)$ are better measured by $m_{\mathrm{b}}$ and the large ones $(M>6.5)$ by $M_{\mathrm{S}}$.

Scordilis (2006) obtained an empirical relationship between $m_{\mathrm{b}}$ and the moment magnitude $\left(M_{\mathrm{w}}\right)$ using earthquake magnitudes reported by the International Seismological Centre (ISC), the National Earthquake Information Center (NEIC), and Harvard University (HRVD). Using the Scordilis (2006) relationships between $m_{\mathrm{b}}$ and $M_{\mathrm{w}}$, for earthquakes with magnitudes $\left(3.5 \leq m_{\mathrm{b}} \leq 6.2\right)$ yields:

$$
M_{\mathrm{w}}=0.85 m_{\mathrm{b}}+1.03 \text {. }
$$

The reported magnitudes of the other three earthquakes are smaller than 6.5. First, the $m_{\mathrm{b}}$ magnitudes converted $M_{\mathrm{w}}$ using Eq. (6). Then, the seismic moment values of these earthquakes were calculated by using the relationship of Kanamori (1983):

$$
M_{\mathrm{w}}=\left(\frac{2}{3}\right) \log M_{\mathrm{o}}-10.7
$$

The seismic moment values which were calculated by Eq. (7) $\left(M_{\mathrm{o}}\right.$ is dyn.cm) of these additional three earthquakes, taking into account the slip rate calculation, given a total released seismic moment re-calculated as $\Sigma M_{0}=3.066 \times$ $10^{17} \mathrm{~N} \mathrm{~m}$. The slip rate is re-calculated for the time period 1965-2009. The calculated actual value of slip rate was found to be $0.41 \mathrm{~mm} /$ year, which is slightly larger than the estimated slip rate values.

\section{Conclusions}

The focal mechanisms of the small-moderate earthquakes which occurred in the Denizli Graben System and the relation to the tectonics have been determined by using both the analysis of $P$-wave polarities and the whole body-wave form of regional seismograms. The major results based on a dataset of 20 reliable fault plane solutions of small earthquakes are as follows:

(1) The earthquakes are characterized by a normal faulting mechanism with large dip angles and small strike-slip components. The depths of all analyzed earthquakes are located in the range $6-8 \mathrm{~km}$.

(2) The stress inversion results reveal a general trend of NE-SW (N9 $\left.{ }^{\circ} \mathrm{E}\right)$ extension for the entire Denizli Graben System. The orientations of the principal stress axes are vertical for $\sigma_{1}$ and horizontal for $\sigma_{2}$ and $\sigma_{3}$. Axes orientations are calculated to be $62^{\circ} / 277^{\circ}$, $28^{\circ} / 100^{\circ}$, and $1^{\circ} / 9^{\circ}$ (Inclination/Direction) for $\sigma_{1}, \sigma_{2}$ and $\sigma_{3}$, respectively. The stress inversion of the studied earthquake focal mechanism data shows that the present-day stress field is characterized by an extensional regime $\left(R^{\prime}=0.74\right)$ and a horizontal direction of extension ( $S_{h \min }$ or $T$ axes) at $\mathrm{N} 9^{\circ} \mathrm{E}$, close to N-S. The $T$ axes indicate that the Denizli Graben is opening in the NE-SW direction.

(3) The extension rate or slip rate is calculated to be 0.41 $\mathrm{mm} /$ year, which is slightly larger than the estimated values for the entire Denizli Graben for the time period 1965-2009.

(4) Focal mechanisms of the analyzed earthquakes, source parameters, and the directions of the horizontal stresses, $S_{H \max }$ and $S_{h \min }$ inferred from the analysis of the focal mechanisms, present good agreement with the general features for the Denizli Graben.

Acknowledgments. The partial support of Kocaeli University, Scientific Project Fund (2010/046), for this study is acknowledged. A special thanks is extended to Dr. Helmut Grosser, Dr. Ertan Pekşen and Dr. Ahmet Karakaş for reviewing this Work. The author thanks two anonymous reviewers for their helpful comments that improved the manuscript.

\section{Appendix A.}

First motion polarities and moment tensor analysis results. a) Focal mechanism obtained from first motion polarities, b) Focal mechanism obtained by moment tensor analysis, c) Details of moment tensor analysis, d) waveform fitting (solid: observed waveform, dashed: calculated waveform). 
Event No: 1
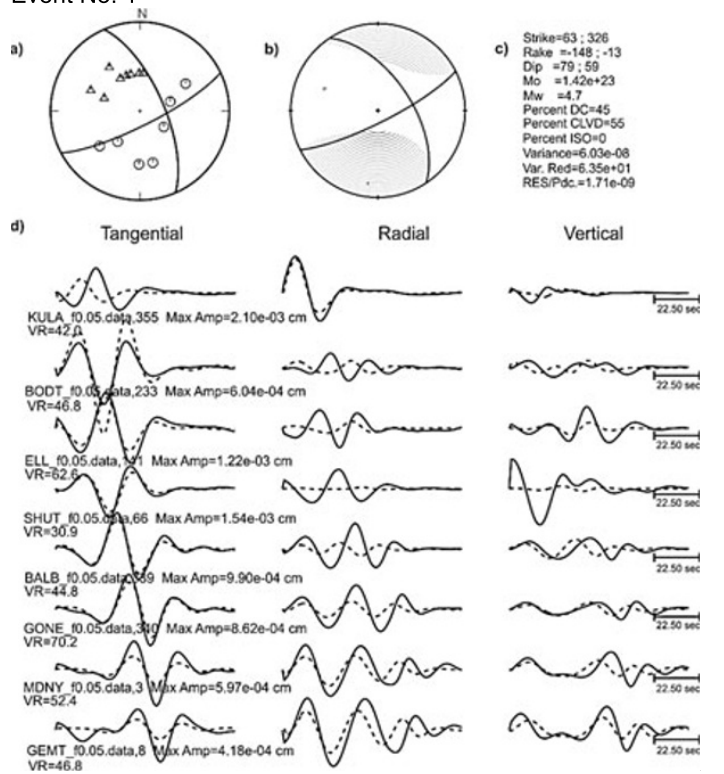

Event No: 2

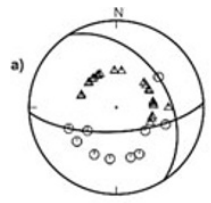

d) Tangential

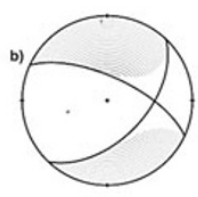

Radial

त.

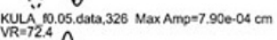

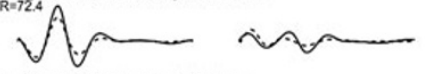

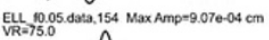

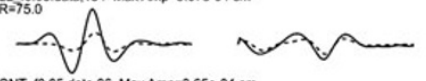

KoNT 10.05.data.86 Max Ampre3.65e-04 cm

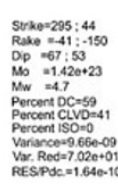

Vertical

i.

i.

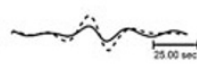

Fig. A.1.

Event No: 3
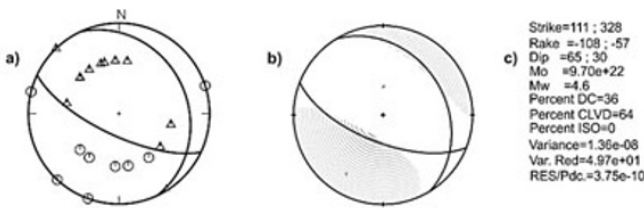

d)

Tangential

Radial

n

YER 10.05.data.200 Max Amp=7.460.-04 cm
VR $=62.5$

:

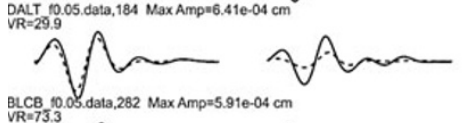

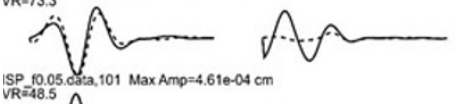

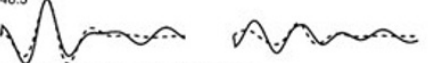

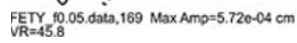

Event No: 4
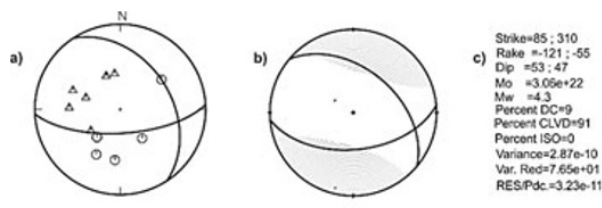

d)

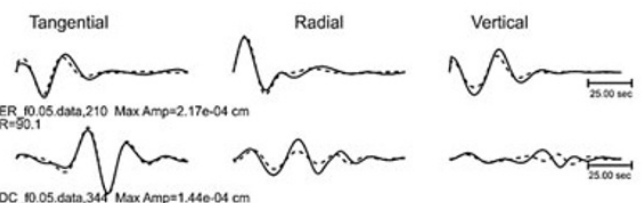

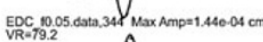

$\sim$ ר

LOKK 0.05.dota,82 Max Amp=1.35e-04 cm
VR=97.0

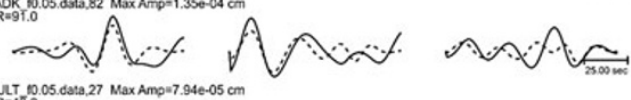

Fig. A.2.

Event No: 5
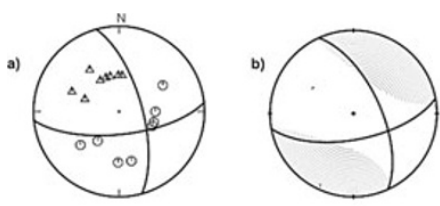

d)

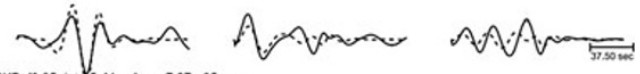

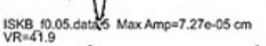

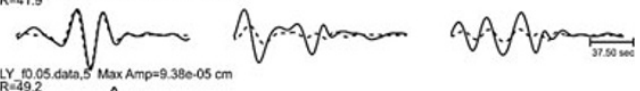

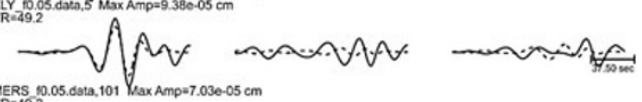

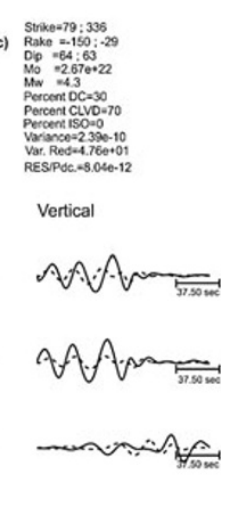

Event No: 6
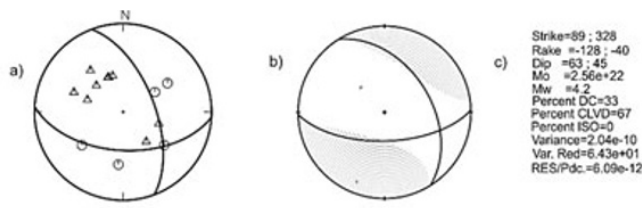

d)

Tangential

Radial

Vertical

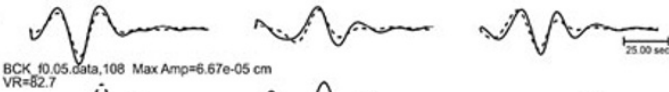

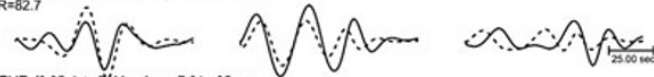

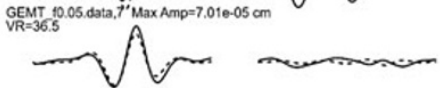

KONT 10.05.data,88 Max Ampa $1.280 .04 \mathrm{~cm}$
VR=82.2.

Fig. A.3. 
Event No: 8
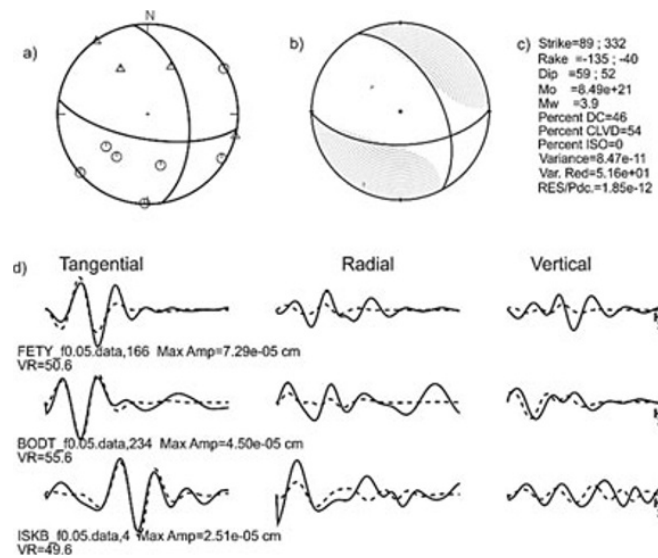

Vertical
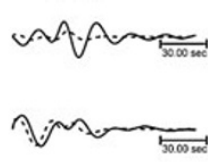

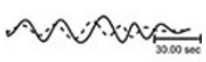

Event No: 9
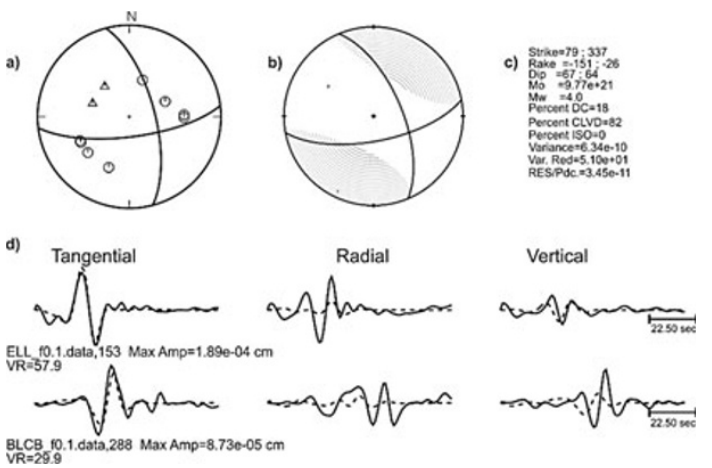

Fig. A.4.

\section{Event No: 10}
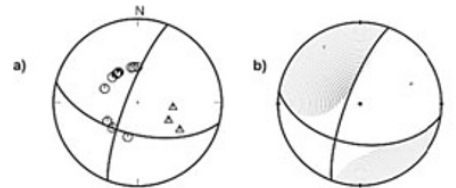

d)

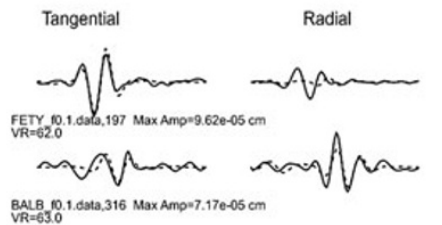

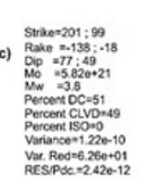

Vertical

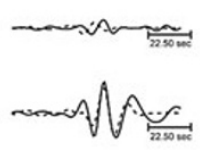

Fig. A.5.

Event No: 14

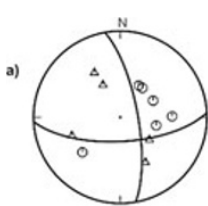

d)

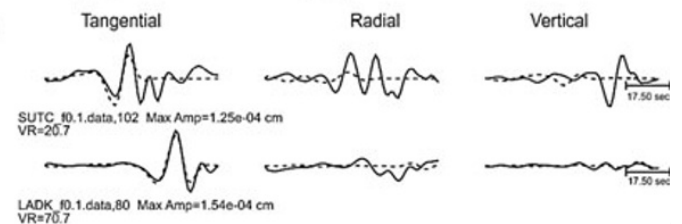

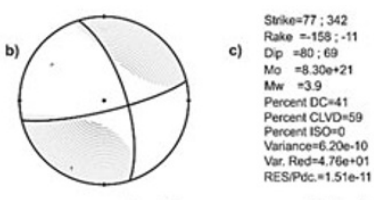

Vertical

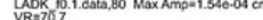

Çakır, Z., Along-strike discontinuity of active normal faults and its influence on Quaternary travertine deposition; Examples from Western Turkey, Turkish J. Earth Sci., 8, 67-80, 1999.

Akyol, N., L. Zhu, B. J. Mitchell, H. Sözbilir, and K. Kekovalı, Crustal structure and local seismicity in Western Anatolia, Geophys. J. Int., doi:10.1111/j.1365-246X.2006.0353, 2006.

Alsan, E., L. Tezucan, and M. Bath, An earthquake catalog for Turkey for the interval 1913-1970, Kandilli Obs., Istanbul and Seismological Inst. Rept., 7-75, 1975.

Altunel, E. and V. Karabacak, Determination of Horizontal extension from fissure- ridge travertines: a case study from the Denizli Basin, southwestern Turkey, Geodinamica Acta, 18(3-4), 333-342, 2005.

Ambraseys, N. N., Engineering seismology, Int. J. Earthq. Eng. Struct. Dyn., 17, 1-105, 1988.

Ambraseys, N. N. and C. F. Finkel, The seismicity of Turkey and adjacent areas: A historical review 1500-1800, Eren Yayıncılık, Istanbul, 1995.

Angelier, J., Inversion of field data in fault tectonics to obtain regional stress. III: A new rapid direct inversion method by analytical means, Geophy. J. Int., 103, 363-376, 1991.

Angelier, J. and P. Mechler, Sur unc methode graphique de recherche des contruirucs principales egalcment utilisnble en tectonique ct en seismologie: La methode des diedrcs droits, Bull. Soc. Osor. Fr., 7(19), 1309-1318, 1977.

Ateş, R. C. and N., Bayülke, The 19 August 1976 Denizli, Turkey, earthquake: Evaluation of the strong motion accelerograph record, Bull. Seismol. Soc. Am., 72(5), 1635-1649, 1982.

Böse, M., E. Hauksson, K. Solanki, H. Kanamori, Y.-M. Wu, and T. H. Heaton, A new trigger criterion for improved real-time performance of on-site early warning in southern California, Bull. Seismol. Soc. Am., doi:10.1785/0120080034, 2009.

Bott, M. H. P., The mechanics of oblique slip faulting, Geol. Mag., 96, 109-117, 1959.

Brune, J. N., Seismic moment, seismicity and rate of slip along the major fault zones, J. Geophys. Res., 73, 777-784, 1968.

Delvaux, D., The TENSOR program for reconstruction: examples from the east African and the Baikal Rift Systems. Terra Abstr., Abstr. suppl., Terra Nova, 5, 216, 1993.

Delvaux, D. and B. Sperner, Stress tensor inversion from fault kinematic indicators and focal mechanism data: The TENSOR program, in New Insights into Structural Interpretation and Modelling, edited by D. Nieuwland, Geol. Soc. Lond. Spec. Publ., vol. 212, pp. 75-100, 2003.

Delvaux, D., R. Moeys, G. Stapel, C. Petit, K. Levi, A. Miroshnichenko, and V. San'kov, Paleostress reconstructions and geodynamics of the Baikal region, Central Asia, Part 2. Cenozoic rifting, Tectonophysics, 282(1), 1-38, 1997.

Dewey, J. F. and A. M. C. Şengör, Aegean and surrounding regions: Complex multiple and continuum tectonics in a convergent zone, Geol. Soc. Am. Bull., 90, 84-92, 1979.

Dreger, D. S., TDMT_INV: Time domain seismic moment tensor INVersion, in International Handbook of Earthquake and Engineering Seismology, edited by W. K. Lee, Boston, Academic Press 81B, 1,627, 2003.

Dreger, D. S. and D. V. Helmberger, Source parameters of the Sierra Madre earthquake from regional and local body waves, Bull. Seismol. Soc. Am., 18, 2015-2018, 1991.

Dreger, D. S. and D. V. Helmberger, Determination of source parameters at regional distances with single station or sparse network data, J. Geophys. Res., 98, 8107-8125, 1993.

Dreger, D. and B. Romanowicz, Source characteristics of events in the San Francisco Bay region, USGS Open-file report, 94-176, 301-309, 1994.

Dreger, D., J. Ritsema, and M. Pasyanos, Broadband analysis of the 21 September, 1993 Klamath Falls earthquake sequence, Geophys. Res. Lett., 22, 997-1000, 1995.

Dreger, D. S., H. Tkalcic, and M. Johnston, Dilational processes accompanying earthquakes in the Long Valley Caldera, Science, 288, 122-125, 2000 
Ergin, K., U. Güçlü, and Z. Uz, A catalog of earthquake for Turkey and surrounding area (11 A.D. to 1964 A.D.), ITU Faculty of Mining Engineering, Istanbul, Turkey, 1967.

Eyidoğan, H. and J. A. Jackson, A seismological study of normal faulting in the Demirci, Alasehir and Gediz earthquake of 1969-1970 in western Turkey: Implications for the nature and geometry of deformation in the continental crust, Geophys. J. R. Astron. Soc., 81, 569-607, 1985.

Eyidoğan, H., U. Güçlü, Z. Utku, and E. Değirmenci, Türkiye Büyük Depremleri Makro-Sismik Rehberi (1990-1988), İTÜ Maden Fak. Jeofizik Müh. Böl., Istanbul, 1991 (in Turkish).

Gee, L. S., D. S. Neuhauser, D. Dreger, M. Pasyanos, R. A. Uhrhammer, and B. Romanowicz, Real-time seismology at UC Berkeley: The Rapid Earthquake Data Integration project, Bull. Seismol. Soc. Am., 86, 936945, 1996.

Gephart, J. W. and D. W. Forsyth, An improved method for determining the regional stress tensor using earthquake focal mechanism data: Application to the San Fernando earthquake sequence, J. Geophys. Res., 89(B11), 9305-9320, doi:10.1029/JB089iB11p09305, 1984.

Gürer, F., N. Kaymakçı, S. Çakır, and M. Özburan, Neotectonics of Southeast Marmara Region (NW Anatolia Turkey), Asian J. Earth Sci., 21, 1041-1051, 2003.

Gutenberg, B. and C. F. Richter, Magnitude and energy of earthquakes, Ann. Geofis., 9, 1-15, 1956.

Herrmann, R. B. and C. Y. Wang, A comparison of synthetic seismograms, Bull. Seismol. Soc. Am., 75, 41-56, 1985.

Holt, W. E., J. F. Ni, T. C. Wallace, and A. J. Haines, The active tectonics of the eastern Himalayan syntaxis and surrounding regions, J. Geophys. Res., 96, 14595-14632, 1991.

Horasan, G., L. Gülen, A. Pınar, D. Kalafat, N. Ozel, S. Kuleli, and A. M. Isıkara, Lithospheric structure of the Marmara and Aegean regions, Western, Turkey, Bull. Seismol. Soc. Am., 92, 332-329, 2002.

http://barbar.koeri.boun.edu.tr/sismo/zKDRS/zzTRwavType.asp (visiting date: 08.04.2010).

ISC, International Seismological Centre, On-line Bulletin, 2010, http://www.isc.ac.uk, Internatl. Seis. Cent., Thatcham, United Kingdom, 2010 .

Jackson, J. and D. McKenzie, Active tectonics of the Alpine-Himalayan belt between Turkey and Pakistan, Geophys. J. R. Astron. Soc., 77, 185264, 1984

Jost, M. L. and R. Herrmann, A student's guide to and review of moment tensors, Seismol. Res. Lett., 60, 37-57, 1989.

Kahle, H.-G., C. Straub, R. Reilinger, S. McClusky, R. King, K. Hurst, G. Veis, K. Kastens, and P. Cross, The strain field in the eastern Mediterranean region, estimated by repeated GPS measurements, Tectonophysics, 294, 237-252, 1998.

Kanamori, H., Magnitude scale and quantification of earthquakes, Tectonophysics, 93(3), 185-199, 1983.

Kaymakçı, N., Kinematic development and paleostress analysis of the Denizli Basin (Western Turkey): Implications of spatial variation of relative paleostress magnitudes and orientations, Asian J. Earth Sci., 27, 207-222, 2006.

Koçyiğit, A., Denizli Horst-Graben System: basin fill, structure, deformational mode, throw amount and episodic evolutionary history, SW Turkey, Geodyn. Acta, 18(3-4), 167-208, 2005.

Koçyiğit, A., H. Yusufoglu, and E. Bozkurt, Evidence from the Gediz Graben for episodic two-stage extension in western Turkey, Journal of Geological Society London, 156, 605-616, 1999.

Langston, C. A., Source inversion of seismic waveforms: the Koyna, India, earthquakes of September 13, 1967, Bull. Seismol. Soc. Am., 71, 1-24, 1981.

McClusky, S. et al., GPS constraints on plate kinematics and dynamics in the eastern Mediterranean and Caucasus, J. Geophys. Res., 105, 56955719, 2000.

McKenzie, D. P., Active tectonics of the Mediterranean Region, Geophys. J. R. Astron. Soc., 30, 109-185, 1972.

Noten Van, K., H. Claes, J. Soete, A. Foubert, M. Özkul, and R. Swennen, Fracture networks and strike-slip deformation along reactivated normal faults in Quaternary travertine deposits, Denizli Basin, Western Turkey, Tectonophysics, 588, 154-170, 2013.
Özalaybey, S., A. Ergin, F. Biçmen, C. Tapırdamaz, A. Yörük, A. Tarancıoğlu, R. Saatçılar, and S. Ergintav, Denizli bölgesindeki mikrodeprem etkinliğinin araştırılması, [Investigation of mikroearthquake activity in Denizli], Scientific Center, Earth Science Research Institute, Project No. 5007102, 15 p., 2000 (in Turkish with an English abstract, unpublished).

Pasyanos, M. E., D. S. Dreger, and B. Romanowicz, Towards Real-Time Determination of Regional Moment Tensors, Bull. Seismol. Soc. Am., 86, 1255-1269, 1996.

Romanowicz, B., D. Dreger, M. Pasyanos, and R. Uhrhammer, Monitoring of strain release in central and northern California using broadband data, Geophys. Res. Lett., 20, 1643-1646, 1993.

Saikia, C. K., Modified frequency-wavenumber algorithm for regional seismograms using Filon's quadrature; modeling of $\mathrm{Lg}$ waves in eastern North America, Geophys. J. Int., 118, 142-158, 1994.

Scherbaum, F., Basic Concepts in Digital Signal Processing for Seismologists, Springer-Verlag New York, Inc (Mar 5 1996), 1994.

Scordilis, E. M., Empirical global relations converting $M_{S}$ and $m_{b}$ to Moment Magnitude, J. Seismol., 10, 225-236. 2006.

Şengör, A. M. C., Cross-faults and differential stretching of hanging walls in regions of low-angle normal faulting: Examples from western Turkey, in Continental Extensional Tectonics, pp. 575-589, edited by M. P. Coward, J. F. Dewey, and P.-L. Hancock, Geol. Soc. London Publication, 1987.

Shomali, Z. H. and R. Slunga, Body wave moment tensor inversion of local earthquakes: An application to the South Iceland Seismic Zone, Geophys. J. Int., 140, 63-70, 2000.

Snoke, J. A., J. W. Munsey, A. G. Teague, and G. A. Bollinger, A program for focal mechanism determination by combined used of polarity and $S V-P$ amplitude ratio data, Earthq. Notes, 55, p. 15, 1984.

Soysal, H., S. Sipahioğlu, D. Koçak, and Y. Altınok, Türkiye ve Çevresinin Tarihsel Deprem Kataloğu (M.Ö. 2100-M.S. 1900) [A Historical Earthquake Catalogue for Turkey and its Surrounding-2100 BC to 1900], Scientific and Technical Research Council of Turkey Project, No. TBAG 341, 87 p., 1981 (unpublished, in Turkish).

Sözbilir, H., Stratigraphy and sedimentology of the Tertiary sequences in the northeastern Denizli province (southwest Turkey), Dokuz Eylüi University, PhD Thesis, 1997 (in Turkish).

Sözbilir, H., Revised Stratigraphy and Facies Analysis of PalaeoceneEocene Supra - allochtonous Sediments (Denizli, SW Turkey) and their Tectonic Significance, Turkish J. Earth Sci., 11, 87-112, 2002.

Sperner, B., B. Müller, O. Heidbach, D. Delvaux, J. Reinecker, and K. Fuchs, Tectonic stress in the Earth's crust: Advances in the World Stress Map project, in New Insights in Structural Interpretation and Modelling, edited by D. A. Nieuwland, Special Publication, Geological Society, London, pp. 101-116, 2003.

Taymaz, T. and S. Price, The 1971 May 12 Burdur Earthquake sequence, SW Turkey-a synthesis of seismological and geological observations, Geophys. J. Int., 108, 589-603, 1992.

Taymaz, T., J. A. Jackson, and D. P. McKenzie, Active tectonics of the north and central Aegean Sea, Geophys. J. Int., 106, 433-490, 1991.

Westaway, R., Neogene evolution of the Denizli region of western Turkey, J. Struct. Geol., 15(1), 37-53, 1993.

Westaway, R., H. Guillou, S. Yurtmen, T. Demir, S. Scaillet, and G. Rowbotham, Investigation of the conditions at the start of the present phase of crustal extension in western Turkey, from observations in and around the Denizli region, Geodinamica Acta, 18, 209-238, 2005.

Zhu, L., N. Akyol, B. J. Mitchell, and H. Sozbilir, Seismotectonics of western Turkey from high resolution earthquake relocations and moment tensor determinations, Geophys. Res. Lett., 33, L07316, doi:10.1029/2006GL025842, 2006.

Zoback, M. L., First and second order patterns of stress in the lithosphere: The World Stress Map project, J. Geophys. Res., 97, 11703-11728, 1992.

T. S. Irmak (e-mail: irmakts@kocaeli.edu.tr) 